\title{
Combination of Gabapentin and Vitamin B12 Compared with Gabapentin Monotherapy on Pain Improvement of Diabetic Neuropathy Patients
}

\author{
Mochamad Firdaus Bhuanaputra, ${ }^{1}$ Alya Tursina, ${ }^{2}$ Yuktiana Kharisma ${ }^{3}$ \\ ${ }^{1}$ Medical Undergraduate Study Program, Faculty of Medicine, Universitas Islam Bandung, Bandung, Indonesia, \\ ${ }^{2}$ Department of Neurology, Faculty of Medicine, Universitas Islam Bandung, Bandung, Indonesia, ${ }^{3}$ Department of \\ Pharmacology, Faculty of Medicine, Universitas Islam Bandung, Bandung, Indonesia
}

\begin{abstract}
Diabetic neuropathy is the most common microvascular complication of diabetes mellitus (DM) occurring in 60$70 \%$ of the world's DM population, $40 \%$ of the DM population in Asia, and $41 \%$ of the DM population in Indonesia. The primary treatment of diabetic neuropathy pain in Indonesia is gabapentin and vitamin B12. The study aimed to compare pain improvements in diabetic neuropathy patients. The drug used was a combination of gabapentin and vitamin B12 and gabapentin monotherapy. For the pain degree measurement, we used the visual analogue scale (VAS). This experimental study was a pretest-posttest randomized control trial using a single-blind method at Dr. M. Salamun Air Force Hospital Bandung from March to May 2017. Samples were 44, type two diabetic neuropathy patients. The Mann-Whitney test to compare pain improvement between 2 groups applied. The results indicated there were differences in pain improvement between diabetic neuropathy patients with gabapentin and vitamin B12 combination compare to gabapentin monotherapy $(\mathrm{p}=0.002)$. This result showed a synergistic effect of gabapentin as an inhibitor of neurotransmitter and vitamin B12 expenditure as an improvement in peripheral nerve cells. This study concluded that gabapentin and vitamin B12 combination is better in improving pain in diabetic neuropathy patients compared to gabapentin monotherapy.
\end{abstract}

Key words: Diabetes mellitus, diabetic neuropathy, gabapentin, pain repair, vitamin B12

\section{Kombinasi Gabapentin dan Vitamin B12 Dibanding dengan Monoterapi Gabapentin terhadap Perbaikan Nyeri Pasien Neuropati Diabetik}

\begin{abstract}
Abstrak
Neuropati diabetik merupakan komplikasi mikrovaskular terbanyak diabetes melitus (DM) yang terjadi pada 60$70 \%$ populasi DM di dunia, 40\% populasi DM di Asia, dan 41\% populasi DM di Indonesia. Pengobatan utama nyeri neuropati diabetik di Indonesia adalah gabapentin dan vitamin B12. Tujuan penelitian ini membandingkan perbaikan rasa nyeri pada pasien neuropati diabetik. Obat yang diberikan adalah kombinasi gabapentin dan vitamin B12 serta monoterapi gabapentin. Pengukuran tingkat nyeri menggunakan visual analogue scale (VAS). Penelitian eksperimental ini adalah pretest-posttest randomized control trial dengan menggunakan metode single-blind yang dilakukan di RSAU Dr. M. Salamun Bandung dari bulan Maret hingga Mei 2017. Sampel berjumlah 44 jenis, dua pasien neuropati diabetik. Sampel berjumlah 44, pasien neuropati diabetik tipe dua. Uji Mann-Whitney dilakukan untuk membandingkan perbaikan nyeri antara 2 kelompok perlakuan. Hasil penelitian menunjukkan terdapat perbedaan perbaikan rasa nyeri pasien neuropati diabetik yang diberi pengobatan kombinasi gabapentin dan vitamin B12 dibanding dengan monoterapi gabapentin $(\mathrm{p}=0,002)$. Hasil ini menunjukkan efek sinergis gabapentin sebagai inhibitor neurotransmiter dan vitamin B12 yang berfungsi memperbaiki sel saraf tepi. Simpulan penelitian ini adalah pengobatan kombinasi gabapentin dan vitamin B12 lebih baik dalam memperbaiki rasa nyeri pada pasien neuropati diabetik dibanding dengan gabapentin saja
\end{abstract}

Kata kunci: Diabetes melitus, gabapentin, neuropati diabetik, perbaikan nyeri, vitamin B12

Received: 12 April 2018; Revised: 5 April 2020; Accepted: 22 April 2020; Published: 30 April 2020

Correspondence: Mochamad Firdaus Bhuanaputra. Medical Undergraduate Study Program, Faculty of Medicine, Universitas Islam Bandung. Jln. Tamansari No. 22, Bandung 40116, West Java, Indonesia. E-mail: mochamadfirdausb@gmail.com 


\section{Introduction}

Diabetic neuropathy is a common complication of diabetes mellitus that happens to $60-70 \%$ of total patients of diabetes mellitus in the world. ${ }^{1}$ The prevalence of neuropathy and complications in the legs is counted high in the patients in Asia, which is about $40 \%$ of the total population of DM. ${ }^{2,3}$ Around $41 \%$ of DM's patients have neuropathy complications in Indonesia. ${ }^{4}$

The symptoms caused are severe and acute pain like burnt, sore, allodynia, and electric shock. This pain has a significant effect on the patient's life quality..$^{-8}$ Currently, there is still no curative diabetic neuropathy treatment. The treatment based on four pillars, such as blood glucose regulation approaching normal, therapy based on pathogenesis, symptomatic treatment, and avoiding risk factors and complications. $5,9,10$

Thepatient needs treatment pharmacologically to relieve symptoms, especially great pain. ${ }^{11}$ Gabapentin is an anti-seizure medication that affects the treatment of neuropathic pain. ${ }^{12-14}$ Gabapentin gives the effect as a substance that can increase gamma-aminobutyric acid (GABA) synthesis, non-N-methyl-D-aspartate (NMDA) receptor antagonist, and $\alpha 2 \delta$ voltage-dependent calcium channels subunit bond that inhibits the release of excitatory neurotransmitters. ${ }^{15,16}$ In most patients, it needs $1.8 \mathrm{gram} /$ day to relieve pain symptoms.

Besides symptomatic treatment, neuropathy patients need a supplement. Vitamin B12 has an essential role in the metabolism of essential fatty acids as the preservation of nerve myelin. Prolonged vitamin B12 deficiency causes nerve cell degeneration and irreversible nerve damage. Diabetic neuropathy with or without vitamin B12 deficiency often treated with neuropathic vitamin for decades. ${ }^{9,17}$

The description above about the effect of both medicines on diabetic neuropathic, the researcher will compare gabapentin combination treatment with or without vitamin B12 to the pain relief in diabetic neuropathic's patients.

\section{Methods}

This experimental study was a pretest-posttest randomized control trial using a single blinding method. The 44 study respondents divided into two groups-the first group consumed gabapentin and vitamin B12 combination, and the second group had gabapentin monotherapy. The patients asked to take the drugs respective to the groups for eight weeks. The pain checks monitored using the monofilament and visual analogue scale (VAS) at the beginning and end of week 8 . Subjects are diabetic neuropathic patients who seek treatment at Dr. M. Salamun Air Force Hospital Bandung from March to May 2017. Statistical analyses used were the Friedman test and Wilcoxon test. The study instrument used is monofilament. ${ }^{18-20}$

This study has been through ethical studies by the Health Research Ethics Committee of the Faculty of Medicine of Universitas Islam Bandung with letter number: 045/Komite Etik. FK/III/2017.

\section{Results}

Table 1 shows that gabapentin and vitamin B12 combination group have pain relief marked by average VAS score reduction in the o weeks until the $8^{\text {th }}$ week.

Table 2 shows that the gabapentin monotherapy treatment group has pain relief marked by average VAS score reduction in the $\mathrm{o}$ weeks until the $8^{\text {th }}$ week.

Based on Table 3 with the Friedman test, the results obtained on the gabapentin

Table 1 Average Result of VAS Score Check in the Gabapentin and Vitamin B12 Combination Group

\begin{tabular}{lcc}
\hline \multirow{2}{*}{ VAS Score } & \multicolumn{2}{c}{ Gabapentin and Vitamin B12 Combination Group } \\
\cline { 2 - 3 } & Average (SD) & Median (Min-Max) \\
\hline VAS o week & $7.45(0.50)$ & $7(7-8)$ \\
VAS 4 $4^{\text {th }}$ week & $7.36(0.49)$ & $7(7-8)$ \\
VAS 8 $8^{\text {th }}$ week & $6.55(0.59)$ & $6.5(6-8)$ \\
\hline
\end{tabular}

Note: VAS=visual analogue scale 
Table 2 Average Result of VAS Score Check in the Gabapentin Monotherapy Group

\begin{tabular}{|c|c|c|}
\hline \multirow{2}{*}{ VAS Score } & \multicolumn{2}{|c|}{ Gabapentin Group } \\
\hline & Average (SD) & Median (Min-Max) \\
\hline VAS o week & $7.27(0.63)$ & $7(6-8)$ \\
\hline VAS $4^{\text {th }}$ week & $6.77(0.61)$ & $7(6-8)$ \\
\hline VAS $8^{\text {th }}$ week & $7.09(0.52)$ & $7(6-8)$ \\
\hline
\end{tabular}

Note: VAS=visual analogue scale

Table 3 VAS Score Different Test Before Therapy, After 4, and 8 Weeks Therapy

\begin{tabular}{lc}
\hline VAS Score & p Value \\
\hline Gabapentin & $<0.001$ \\
Gabapentin and vitamin B12 combination & $<0.001$ \\
\hline
\end{tabular}

Note: * Statistic analysis with Friedman test, significant if $\mathrm{p}$ value $\leq 0.05$

Table 4 The Difference of Pain Relief Before Therapy, After 4 and 8 Weeks Therapy

\begin{tabular}{|c|c|c|c|c|c|c|}
\hline \multirow{2}{*}{ Time } & \multicolumn{3}{|c|}{ Gabapentin Monotherapy } & \multicolumn{3}{|c|}{$\begin{array}{c}\text { Gabapentin and Vitamin B12 } \\
\text { Combination }\end{array}$} \\
\hline & $\begin{array}{l}\text { Average } \\
\text { (SD) }\end{array}$ & $\begin{array}{l}\text { SVAS } \\
\text { Score }\end{array}$ & $\underset{\text { Value }^{*}}{\mathbf{p}}$ & $\begin{array}{l}\text { Average } \\
\text { (SD) }\end{array}$ & $\begin{array}{l}\text { SVAS } \\
\text { Score }\end{array}$ & $\begin{array}{c}\text { p } \\
\text { Value }\end{array}$ \\
\hline o weeks & $7.27(0.63)$ & 18 & م ח ח & $7.45(0.50)$ & 001 & $<0001$ \\
\hline $8^{\text {th }}$ week & $7.09(0.52)$ & 0.10 & 0.020 & 6.54 (0.59) & 0.91 & $<0.001$ \\
\hline
\end{tabular}

Note: "Data analysis uses Wilcoxon test, significant if $\mathrm{p}$ value $\leq 0.05 ; \Delta=$ difference between weeks

Table 5 Pain Relief Comparison between Gabapentin and Vitamin B Combination and Gabapentin Monotherapy

\begin{tabular}{|c|c|c|c|c|c|c|c|}
\hline \multirow{2}{*}{ Pain Relief } & \multicolumn{3}{|c|}{$\begin{array}{l}\text { Gabapentin } \\
\text { Monotherapy }\end{array}$} & \multicolumn{3}{|c|}{$\begin{array}{l}\text { Gabapentin and Vitamin } \\
\text { B12 Combination }\end{array}$} & \multirow{2}{*}{$\stackrel{\text { p }}{\text { Value }}$} \\
\hline & Mean & SD & Median & Mean & SD & Median & \\
\hline $\begin{array}{l}\Delta \text { VAS score of o week } \\
\text { and } 8^{\text {th }} \text { week }\end{array}$ & 0.18 & 0.58 & 0.00 & 0.90 & 0.29 & 1.00 & 0.002 \\
\hline
\end{tabular}

Note: "Mann-Whitney test, $\Delta=$ difference between weeks

monotherapy test and gabapentin and also vitamin B12 combination, which shows that each has a significant different VAS score on two measurements.

Table 4 shows that there is a significant average difference in pain relief between o week and $8^{\text {th }}$ week in both groups. The gabapentin and vitamin B12 combination group has better average pain relief compared to the gabapentin monotherapy group.
Table 5 shows that there is a significant difference in pain relief between gabapentin and vitamin B12 combination group and gabapentin monotherapy ( $\mathrm{p}$ value $<0.002$ ).

\section{Discussion}

In the gabapentin and vitamin B12 combination group, there is a significant pain relief difference ( $p$ value<0.001) between 0 week and eighth 
week. This result was consistent with the study conducted by Mimenza Alvarado and Aguilar Navarro. ${ }^{21}$ They stated that there is a significant pain relief difference ( $\mathrm{p}$ value $<0.001$ ).

Gabapentin and vitamin B12 have synergistic workability. The gabapentin increases gammaaminobutyric acid (GABA) synthesis, the receptor antagonist of N-methyl-D-aspartate (NMDA), and subunit bond of $\alpha_{2} \delta$ voltage-dependent calcium channels that inhibits the release of excitatory neurotransmitters. That mechanism causes stimulation inhibition and pain reduction in neuropathic patients who consume gabapentin. The role of vitamin B12 is to repair peripheral nerve cells by becoming a cofactor that facilitates homocysteine methylation for methionine, which activated to S-adenosyl-methionine, which donates the methyl group for methyl acceptors like myelin, neurotransmitter, and phospholipid membrane. The usage of gabapentin combined with vitamin B12 has a synergic effect to relieve the pain of diabetic neuropathic patients..$^{15,16,22}$

In the gabapentin treatment groups, a significant pain relief difference is observed ( $p$ value $=0.02$ ) between 0 week and eighth week. This study is following the study conducted by Surcheva et al., ${ }^{23}$ which shows that there is a significant pain relief difference ( $p$ value $=001$ ). The difference in improvement observed during o week and eighth week.

Gabapentin is a medicine of choice which mitigates the pain that works on the central nervous systembuthas a sideeffect that is classified small. Gabapentin affects neurotransmitter inhibitors. Gabapentin has a modification effect of releasing GABA. The release of GABA happened either presynaptic or postsynaptic on the central or even the arrangement of peripheral nerves. Gabapentin increases GABA synthesis from glutamate and increases the release of GABA from astrocytes. Some researches show that there is a concentration increase of GABA in some regions of the brain after the administration of gabapentin so that glutamic acid decarboxylase increases and also decarboxylase glutamic acid enzyme destruction decreases which eventually increases the production of GABA..$^{15,16,23}$

The pain relief observed in the gabapentin and vitamin B12 combination group and gabapentin monotherapy group. The pain relief is significantly better in the gabapentin and vitamin B12 combination group compared to the gabapentin monotherapy group with $\mathrm{p}$ value $=0.002$.
The finding is consistent with the study conducted by Mimenza Alvarado and Aguilar Navarro. ${ }^{21}$ The gabapentin and vitamin B complex administration compare to pregabalin shows better pain relief. The significant difference in pain relief between the treatment group and the control group observed in the o week and eighth week ( $\mathrm{p}$ value $<0.001$ ).

Gabapentin and vitamin B12 combination groups have better pain relief improvement than the gabapentin monotherapy group. The results caused by better and more optimal treatment mix in gabapentin and vitamin B12 combination group. The administration of gabapentin will give an inhibiting effect to release neurotransmitters so that it will reduce the pain in diabetic neuropathic patients. The usage combined with the administration of vitamin B12, which serves to maintain and repair peripheral nerve cells. The combination treatment effect will give better pain relief improvement. ${ }^{23-25}$

\section{Conclusion}

A combination of gabapentin and vitamin B12 showed better pain relief compared to gabapentin monotherapy in diabetic neuropathic patients.

\section{Conflict of Interest}

The authors declare that no conflict of interest in this study.

\section{Acknowledgment}

We appreciate the support from the Head of Dr. M. Salamun Air Force Hospital Bandung during the study.

\section{References}

1. Bansal D, Gudala K, Muthyala H, Esam HP, Nayakallu R, Bhansali A. Prevalence and risk factors of development of peripheral diabetic neuropathy in type 2 diabetes mellitus in a tertiary care setting. J Diabetes Investig. 2014;5(6):714-21.

2. Ramachandran A, Snehalatha C, Shetty AS, Nanditha A. Trends in prevalence of diabetes in Asian countries. World $\mathrm{J}$ Diabetes. 2012;3(6):110-7.

3. Guariguata L, Whiting DR, Hambleton I, Beagley J, Linnenkamp U, Shaw JE. Global 
estimates of diabetes prevalence for 2013 and projections for 2035. Diabetes Res Clin Pract. 2014;103(2):137-49.

4. Indonesia Agency of Health Research and Development, Ministry of Health of Republic of Indonesia. Basic health research (Riskesdas) 2013 [Internet]. Jakarta: Indonesia Agency of Health Research and Development, Ministry of Health of Republic of Indonesia; 2013 [cited 2017 June 15]. Available from: http://labdata.litbang. kemkes.go.id/ccount/click.php?id=10.

5. Malik VS, Popkin BM, Bray GA, Després JP, Willett WC, Hu FB. Sugar-sweetened beverages and risk of metabolic syndrome and type 2 diabetes: a meta-analysis. Diabetes Care. 2010;33(11):2477-83.

6. Jin W, Patti ME. Genetic determinants and molecular pathways in the pathogenesis of type 2 diabetes. Clin Sci (Lond). 2009;116(2):99-111.

7. VA Center for Integrated Healthcare. Diabetic neuropathies: the nerve damage of diabetes [Internet]. July 2013 [cited 2017 June 16]. Available from: https://www.mirecc.va.gov/ cih-visn2/Documents/Provider_Education_ Handouts/Diabetic_Neuropathies_ Version_3.pdf.

8. Chawla R. Complications of diabetes. New Delhi: Jaypee Brothers Medical Publishers; 2012.

9. Schreiber AK, Nones CF, Reis RC, Chichorro JG, Cunha JM. Diabetic neuropathic pain: physiopathology and treatment. World J Diabetes. 2015 Apr 15;6(3):432-44.

10. Yagihashi S, Mizukami H, Sugimoto K. Mechanism of diabetic neuropathy: where are we now and where to go? J Diabetes Investig. 2011;2(1):18-32.

11. Emerging Risk Factors Collaboration, Sarwar N, Gao P, Seshasai SR, Gobin R, Kaptoge S, Di Angelantonio E, et al. Diabetes mellitus, fasting blood glucose concentration, and risk of vascular disease: a collaborative metaanalysis of 102 prospective studies. Lancet. 2010;375(9733):2215-22.

12. Wiffen PJ, Derry S, Moore RA, Aldington D, Cole P, Rice AS, et al. Antiepileptic drugs for neuropathic pain and fibromyalgia - an overview of Cochrane reviews. Cochrane Database Syst Rev. 2013;(11):CDo10567.

13. Wiffen PJ, Derry S, Bell RF, Rice AS, Tölle TR, Phillips T, et al. Gabapentin for chronic neuropathic pain in adults. Cochrane Database Syst Rev. 2017;6:CDoo7938.

14. Murnion BP. Neuropathic pain: current definition and review of drug treatment. Aust Prescr. 2018 Jun;41(3):60-3.

15. Attal N, Cruccu G, Baron R, Haanpää M, Hansson P, Jensen TS, et al. EFNS guidelines on the pharmacological treatment of neuropathic pain: 2010 revision. Eur J Neurol. 2010;17(9):1113-23.

16. Rosenquist RW, Vrooman BM. Chronic pain managament. In: Butterworth JF, Mackey DC, Wasnick JD, editors. Morgan and Mikhail's Clinical Anesthesiology. $5^{\text {th }}$ Edition. New York: McGraw-Hill Companies; 2013. p. 1023-86.

17. Agency for Healthcare Research and Quality, U.S. Department of Health \& Human Services. Effectiveness of treatments for diabetic peripheral neuropathy [Internet]. May 13, 2016 [cited 2017 June 17]. Available from: https://effectivehealthcare.ahrq.gov/sites/ default/files/pdf/diabetic-neuropathy_ research-protocol.pdf.

18. Baraz S, Zarea K, Shahbazian HB, Latifi SM. Comparison of the accuracy of monofilament testing at various points of feet in peripheral diabetic neuropathy screening. J Diabetes Metab Disord. 2014;13(1):19.

19. Wang F, Zhang J, Yu J, Liu S, Zhang R, Ma $\mathrm{X}$, et al. Diagnostic accuracy of monofilament tests for detecting diabetic peripheral neuropathy: a systematic review and metaanalysis. J Diabetes Res. 2017;2017:8787261.

20. Dros J, Wewerinke A, Bindels PJ, van Weert HC. Accuracy of monofilament testing to diagnose peripheral neuropathy: a systematic review. Ann Fam Med. 2009 NovDec;7(6):555-8.

21. Mimenza Alvarado A, Aguilar Navarro S. Clinical trial assessing the efficacy of gabapentin plus B complex (B1/B12) versus pregabalin for treating painful diabetic neuropathy. $J$ Diabetes Res. 2016;2016:4078695.

22. Jayabalan B, Low LL. Vitamin B supplementation for diabetic peripheral neuropathy. Singapore MedJ.2016;57(2):559.

23. Surcheva S, Todorova L, Maslarov D, Vlaskovska M. Preclinic and clinic effectiveness of gabapentin and pregabalin for treatment of neuropathic pain in rats 
and diabetic patients. Biotechnol Biotechnol Equip. 2017;31(3):568-73.

24. Vinik AI, Casellini CM. Guidelines in the management of diabetic nerve pain: clinical utility of pregabalin. Diabetes Metab Syndr Obes. 2013;6:57-78.
25. Lal R, Sukbuntherng J, Luo W, Tovera J, Lassauzet ML, Cundy KC. Population pharmacokinetics and pharmacodynamics of gabapentin after administration of gabapentin enacarbil. J Clin Pharmacol. 2013;53(1):29-40. 